Filozofska fakulteta, Univerza v Ljubljani

Slovenija

darja.mertelj@ff.uni-lj.si

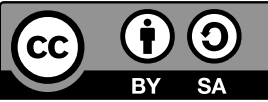

\title{
HRVATSKO-TALJANSKI RJEČNIK ŠKOLSKOG JEZIKA, 1. svezak, Priručnik za studente i nastavnike taljanskog jezika / \\ DIZIONARIO CROATO-ITALIANO DEL LINGUAGGIO SCOLASTICO, Volume 1, Manuale per studenti e insegnanti d'italiano
}

Mardešić, Sandra/ Lütze-Miculinić, Marija (2021). Hrvatsko-talijanski riječnik školskog jezika: 1. Svezak: Priručnik za studente i nastavnike taljanskog jezika / Dizionario croato-italiano del linguaggio scolastico: Volume 1: Manuale per studetni e insegnanti d'italiano. Zagreb: Hrvatsko filološko društvo. ISBN: 978-953-296-157-7, mehka vezava, 284 strani, 130 hrk oz. 17,30€

Šolski jezik je zvrst praviloma standardnega jezika, ki jo uporabljajo vsi udeleženci šolskega življenja pri svojem vsakodnevnem sporazumevanju med učnim procesom in zunaj njega: komunikacija s starši, z lokalnimi in mednarodnimi ustanovami in s strokovnjaki področja. Učiteljev jezik pa je podzvrst, kjer gre za govor učitelja v razredu, ki vključuje tudi strokovno in specifično izrazoslovje tega področja, še nadalje pa so specifike prisotne, ko gre za učitelja tujega/drugega jezika. Ker so dela s tega področja sorazmerno redka, obenem pa gre za zelo živo potrebo učiteljev (in učencev) pri pouku tujega/drugega jezika, so znanstvena preučevanja in priročniki s tega področja za marsikoga $v$ teh kontekstih lahko zelo dobrodošli.

Pričujoči priročnik oz. glosar šolskega jezika je nastajal na Hrvaškem, v obdobju od 2015 do 2020, kot skupni podvig hrvaških glotodidaktičark štirih tujih/drugih jezikov, ki se poučujejo v hrvaških javnih šolah. Predmet preučevanja je bilo področje šolskega jezika pri pouku nemščine, angleščine, francoščine in italijanščine. V priročniku je zajet tako govorjeni jezik, kot so ga uporabljali učitelji in učenci v široki mreži sodelujočih šol, kot tudi izsledki preučevanja šolske dokumentacije, intervjujev s številnimi pristojnimi strokovnjaki s področja šolstva in učiteljev, ter iz primerjalnih študij. 
Med jeziki v projektih je tudi italijanščina, ki se ga v šolskih sistemih uči in/ali poučuje kot prvi, drugi ali tuji jezik tako na Hrvaškem kot v Sloveniji (v predšolskih in šolskih izobraževalnih ustanovah, podobno kot v Sloveniji). Četudi gre v Sloveniji za veliko manjše obsege, bi utegnil biti pričujoči priročnik zanimiv in uporaben tako za učitelje italijanščine (ki ga poučujejo v omenjenih družbeno-kulturnih kontekstih), morda pa tudi za učitelje hrvaščine kot prvega, drugega ali tujega jezika. Zanimive vpoglede bi utegnil nuditi tudi drugim raziskovalcem, tako jezikoslovcem kot glotodidaktikom. Avtorici sta se odločili, da zaradi specifičnih vlog italijanščine izpostavita predvsem različne socio- in pragma-lingvistične vidike:

a) v uvodnem delu so predstavljene raznolike vloge italijanskega jezika (kot prvega ali drugega, kot jezika narodne manjšine ali izvornega jezika) v Italiji in drugje $\mathrm{v}$ Evropi, predvsem na Hrvaškem in v Sloveniji;

b) zatem avtorici zožita perspektivo na šolsko oz. izobraževalno polje in kratko orišeta raznolike pod-kategorije strokovnega zvrsti »šolskega jezika kot jezika stroke« (ki vključuje jezikovne kode vseh vključenih v to polje, vključno z učenci);

c) $\mathrm{v}$ tretjem delu orišeta naravno prepletenosti šolskega sporazumevalnega polja $\mathrm{z}$ vidiki kulture in medkulturne kompetence (vključujoč SEJO, dodatek k SEJO, Byramov in Balbonijev model medkulturne kompetence) ter njuno povezanost s specifično komunikacijsko situacijo učiteljev in učencev na Hrvaškem;

d) v četrtem delu avtorici poglobita in izčrpno predstavita številne vidike medkulturnih razlik na področjih učenčevega in učiteljevega jezika, s številnimi primeri iz hrvaške javne izobraževalne vertikale od vrtcev do fakultet: v šolskem kontekstu, pogojenim z izobraževalnim sistemom, so družbene in medkulturne ter pragmatične kompetence ključne;

e) v zadnjem delu so sistematično navedeni primarni in sekundarni viri raziskave, ki je podlaga pričujočemu slovarju.

V osrednjem hrvaško-italijanskem glosarskem delu priročnika najdemo 400 hrvaških in 750 italijanskih strokovnih izrazov s področja šolstva, plod sistematične analize z uporabo kontrastivne pragmatike. Številni med njimi so vzkliki, pozdravi, onomatopeje, ki se pojavljajo v šolskih razredih, torej ne gre le za pretežno učiteljev jezik ali jezik šolske dokumentacije. Številni izrazi so dodatno označeni kot npr. regionalizmi, pogovorni vzkliki, žargon ipd. Zelo dragocen doprinos slovarja so nedvomno primeri uporabe posamičnega izraza v primeru komunikacije (v vzklikih, vprašanjih, povedih, kratkih dialogih ipd.) - vsi v hrvaški in italijanski različici, vsi iz ust različnih šolskih protagonistov. Ob marsikaterem se lahko prisrčno nasmejimo, saj se spomnimo iskrivih trenutkov v šolskem življenju razredov s tujim ali drugim jezikom in (tudi jezikovne) ustvarjalnosti, ki nastaja v njih.

Številne strokovne izraze spremljajo zgoščena pojasnila, ki izhajajo iz medkulturnih razlik obeh šolskih okolij, ki odražajo hrvaški in italijanski izobraževalni sistem 
(primerjavo s slovenskim pa si lahko ob prebiranju soustvarjamo). Le nekateri hrvaški strokovni izrazi imajo 'ustreznice' v standardni italijanščini, z določenimi omejitvami, nekateri izrazi imajo le delno enakovredne 'ustreznice', nekateri pa jih sploh nimajo. Celota pravzaprav predstavlja primer jezikovne zvrsti, ki se samostojno uporablja zunaj italijanskega državnega ozemlja. Prav ta del šolskega, učiteljevega in učenčevega jezika, je lahko pomemben vir za poglobitev medkulturnega znanja dvojezičnih učencev in študentov, učiteljev italijanščine v različnih kontekstih, pa morda tudi za spodbujanje medkulturnih veščin v priložnostnih 'mediacijah' v stiku med (rojenimi) italijanskimi in hrvaškimi govorci, drugimi govorci oz. uporabniki italijanščine in hrvaščine, sami pa si lahko ustvarjamo analogijo s slovenščino v Sloveniji in v slovenskih šolah v zamejstvu.

Marsikje lahko zaznamo, da v primeru šolskega jezika tradicija prevlada nad pravilnostjo uporabe določenih izrazov in da bi bile potrebne nadaljnje raziskave in posodobitve s ciljem še boljše medkulturne komunikacije. Z poglabljanjem svojih medkulturnih veščin, povezanih z razlikami med izobraževalnimi sistemi med tremi državami, lahko učitelji dodatno uveljavljajo svojo profesionalnost, med učenci pa lahko spoznavanje teh 'vsakdanjih' razlik spodbuja njihovo radovednost. Ne nazadnje je to živo in dinamično področje (prvega/drugega/tujega) strokovnega jezika vredno tudi raziskovanja ne le z jezikoslovno-leksikografskih pač pa tudi z glotodidaktičnih vidikov. 